\title{
Pengelolaan Pembelajaran Dalam Proses Pengembangan Sosial Emosional Standar Pendidikan Anak Usia Dini
}

\author{
(Studi Kasus PAUD Az-Zahra Islamic Preschool Cicalengka Kabupaten Bandung)

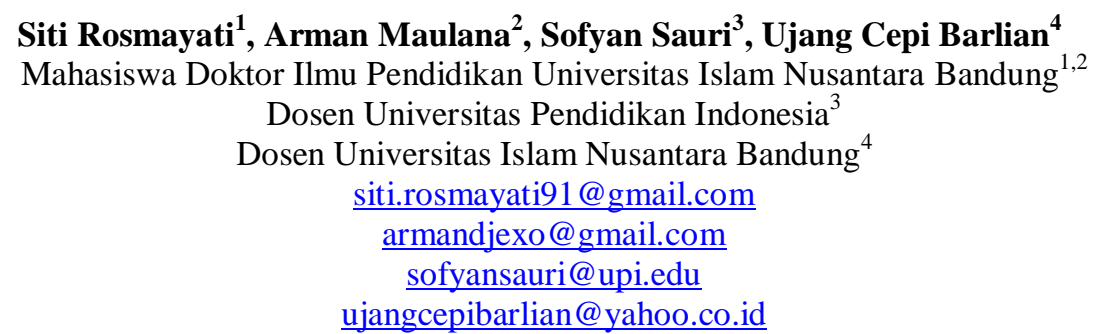

\begin{abstract}
Abstrak
Berkaitan dengan analisis data yang bersifat deskriptif maka penelitian ini akan di uraikan dari hasil dokumentasi dan observasi ke lapangan analisis dari pengelolaan pembelajaran dalam proses pengembangan sosial emosional Pendidikan Anak Usia Dini Az-Zahra Islamic Preschool Cicalengka Kabupaten Bandung. Hasil dokumentasi analisis yang dilakukan oleh peneliti pada pengelolaan pembelajaran dalam proses pengembangan sosial emosional usia 4-5 tahun dari 17 anak di Pendidikan Anak Usia Dini Az-Zahra Islamic Preschool Cicalengka Kabupaten Bandung. Ada beberapa indikator dalam pengelolaan pembelajaran: 1) rencana 2) pelaksanaan pembelajaran yaitu kegiatan sebelum kelas, kegiatan awal, kegiatan inti, kegiatan diet dan istirahat, dan kegiatan akhir 3) evaluasi yaitu evaluasi, pelaporan dan tindak lanjut. Kemudian Anda bisa menyimpulkan Pengelolaan pembelajaran dalam proses pengembangan sosial emosional Pendidikan Anak Usia Dini Az-Zahra Islamic Preschool Cicalengka Kabupaten Bandung Meskipun masih ada dua indikator yang belum dilaksanakan, namun guru masih berprestasi sesuai dengan indikatornya. Dilihat dari tingkat perkembangan sosial dan emosional anak, keberhasilan guru sudah baik.
\end{abstract}

Kata Kunci: Pengelolaan Pembelajaran, Perkembangan Sosio Emosional Anak.

\begin{abstract}
In connection with descriptive data analysis, this research will be described from the results of documentation and field observations from the analysis of learning management in the process of social emotional development of Az-Zahra Islamic Early Childhood Education at Cicalengka Preschool, Bandung Regency. The results of the analysis documentation carried out by researchers on the management of learning in the process of social emotional development aged 4-5 years of 17 children in the Az-Zahra Islamic Preschool Cicalengka Early Childhood Education, Bandung Regency. There are several indicators in learning management: 1) plan 2) implementation of learning, namely pre-class activities, initial activities, core activities, diet and rest activities, and final activities 3) evaluation, namely evaluation, reporting and follow-up. Then you can conclude the management of learning in the process of social emotional development of Early Childhood Education Az-Zahra Islamic Preschool Cicalengka, Bandung Regency. Although there are still two indicators that have not been implemented, the teacher is still achieving according to the indicators Judging from the level of children's social and emotional development, teacher success already well.
\end{abstract}

Keywords: Learning Management, Children's Socio-Emotional Development. 
46 Coopetition, Vol XII, Nomor 1, Maret 2021, 45 - 54

(E-ISSN : 2615-4978, P-ISSN : 2086-4620)

\section{PENDAHULUAN}

Guru adalah pemberi stimulus yang efektif pada pendidikan formal, peran guru tidak dapat dibantah, jika guru berada di lingkungan belajar sekolah maka guru merupakan tonggak penting. Pengaruh guru terhadap siswa dapat mempengaruhi cara siswa belajar dan bekerja di masa depan. Guru adalah orang utama untuk mencapai tujuan tersebut, guru juga dituntut untuk menguasai pengetahuan dan keterampilan agar proses pengajaran menjadi lebih nyaman. Menurut Fory (2016) bahwa tujuan perkembangan sosio emosional juga merupakan bantuan untuk meningkatkan kualitas sosial dan emosional yang penting bagi keberhasilan anak didik. Strategi perkembangan sosial afektif merupakan salah satu bentuk kegiatan stimulasi yang bertujuan dalam meningkatkan kompetensi sosial emosional anak. Diharapkan dengan pemberian rangsangan tepat, perkembangan emosi dan sosial anak akan meningkat, dan diharapkan kedepannya mereka lebih ideal. Menurut Mulyasa (2012) pewarisan semua kegiatan prasekolah dalam membahagiakan anak melalui bermain, melalui permainan anak dalam belajar memberikan daya kemampuan sosial emosional serta perilaku diharapkan bisa bersosialisasi di lingkungan sekitar yang dihadapinya dan diterima dalam norma sosial. Strategi perkembangan emosional sosial anak aktivitas yang di libatkan seperti menyanyi, mendongeng, dan permainan sosial / kelompok.

Dalam arti luas, pengelolaan mengacu pada perencanaan, pengorganisasian, pembinaan dan pengendalian aspek sumber daya manusia organisasi untuk dapat mencapai tujuan yang produktif. Saat ini, berbagai ahli mendefinisikan istilah yang digunakan untuk merepresentasikan pekerjaan dari aktivitas pelayanan dengan berbagai cara, guru besar di bidang Ilmu Pendidikan yang di ilhami Mulyasa (2012) percaya bahwa pengelolaan adalah perencanaan, pengorganisasian, pengarahan dan pengawasan pekerjaan organisasi. Proses dan gunakan semua sumber daya organisasi yang tersedia untuk mencapai tujuan (Maulana, 2020), percaya bahwa pengelolaan mencakup konsep lima fungsi utama, yakni mendesain, mengatur, menyesuaikan, mengkoordinasikan, mengontrol.

Untuk dapat memberikan pembelajaran yang efektif sebagai tujuan yang di inginkan lembaga pendidikan guru harus memiliki kemampuan mengajar yaitu kemampuan seseorang dalam mengelola pembelajaran anak, termasuk memahami siswa, merancang dan melaksanakan pembelajaran, mengevaluasi dan melaksanakan pembelajaran, serta membina anak dalam mengembangkan potensinya.

Menurut Suharsimi (1996) tujuan dari manajemen pembelajaran adalah memungkinkan setiap anak dalam belajar bersama temannya di kelas sesuai dengan prosedur sehingga dapat pencapaian tujuan pada pembelajaran dengan efektif dan efisien. Pembelajaran efektif berarti anak bisa kelihatan dari aspek perkembangan dalam berbagai potensi yang ada pada anak sehingga menghasilkan keterampilan kompetensi yang berkontribusi pada perkembangan otak, bahasa, rasionalitas dan interaksi sosial. Dalam hal ini berarti bahwa pengelolaan pembelajaran adalah upaya untuk melakukan proses pembelajaran dengan menetapkan strategi dan rencana, melaksanakan dan mengevaluasi, agar tercipta proses pembelajaran yang efektif dan efisien.

Perkembangan sosial emosional mengacu pada perkembangan perilaku anak saat mereka beradaptasi dengan aturan yang berlaku di komunitas tempat mereka tinggal. Emosi sosial dapat didefinisikan sebagai perilaku yang menyertai perasaan tertentu ketika berhadapan dengan orang lain.

Perkembangan anak didik pada usia 4-5 tahun cukup pesat, terutama dalam perkembangan sosial emosional anak sehari-hari dalam kehidupan yang terlihat. Misalnya, perkembangan sosio emosional terjadi pada usia 4-5 tahun, interaksi pada anak dapat dimulai bersama teman sebayanya dengan cara berkomunikasi sesama teman, lawan bermain, bersosialisasi dengan sesama jenis dan berinteraksi menangis di hadapan temannya. Pada saat yang sama, perkembangan emosi anak usia 4-5 tahun adalah mereka akan mengungkapkan perasaan emosionalnya melalui tangisan, tawa, senyum, ketakutan, kemarahan dan agresi.

Menurut penelitian Ukti, (2015) tingkatan pencapaian perkembangan sosial dan emosional yaitu 1) Banggalah dengan kesuksesan 2) Membuat sesuatu karena imajinasi dominan 3) Percayalah pada pekerjaan rumah 4) Menceritakan kembali peristiwa atau pengalaman masa lalu 5) Gunakan barang orang lain dengan hati-hati 6) Karena peringatan, harap hentikan perilaku yang tidak pantas 7) Punya beberapa teman dan 8) Puji dan dorong anak lain.

Menurut Setiadi Susilo memuat tingkat perkembangan sosial emosional yang tercapai pada anak usia 4-5 tahun, sebagai berikut:

Tabel 1 Indikator pencapaian perkembangan sosial emosioanal pada anak usia dini umur 4-5 tahun

\begin{tabular}{|c|c|}
\hline $\begin{array}{c}\text { Lingkup } \\
\text { Perkembangan }\end{array}$ & $\begin{array}{c}\text { Tingkat Pencapaian } \\
\text { Perkembangan Usia 4-5 }\end{array}$ \\
\hline $\begin{array}{c}\text { Sosial } \\
\text { emosional }\end{array}$ & $\begin{array}{l}\text { 1. Tunjukkan sikap mandiri saat memilih } \\
\text { aktivitas } \\
\text { 2. Bersedia berbagi, membantu dan } \\
\text { membantu teman. } \\
\text { 3. Kendalikan emosi. } \\
\text { 4. Ikuti aturan yang berlaku di dalam } \\
\text { game. } \\
\text { 5. Hormati orang lain }\end{array}$ \\
\hline
\end{tabular}

Sumber: Setiadi susilo, 2020 . 
Berdasarkan pandangan di atas, penulis menyimpulkan bahwa indikator pencapaian perkembangan sosial dan emosional anak usia 4-5 tahun adalah sebagai berikut: review peristiwa atau pengalaman masa lalu. Gunakan barang milik orang lain dengan hati-hati. Berhenti mengutuk perilaku yang tidak pantas.

Anak mempunyai pemahaman dalam memahami aturan, sudah bisa berinteraksi dalam permainan bersama teman sebayanya, menunjukkan mandiri dalam bersikap saat memilih suatu kegiatan, berbagi bersama temannya, saling membantu sesama teman dan menghargai sesama temannya.

Menurut penelitian Sary Yulia, Yusrizal (2015) perlu adanya perencanaan, pengorganisasian, pelaksanaan dan pengendalian, kemudian disingkat menjadi POAC. Perkembangan sosio emosional pada anak masih ada anak yang pencapaian perkembangan sosial emosionalnya masih belum optimal atau perlu ditingkatkan karena perkembangannya yang belum ideal. Bahwa karena perkembangan sosial anak belum optimal maka perlu dilakukan perbaikan masalah-masalah yang berkaitan dengan perkembangan sosial dan emosional, serta perlu dilakukan pengembangan keterampilan sosial anak.

\section{Perumusan Masalah}

Berdasarkan uraian pendahuluan, maka dapat di tarik sebuah pertanyaan: bagaimana mengelola pembelajaran dalam proses perkembangan sosial dan emosional anak usia 4-5 tahun di PAUD AzZahra Islamic Preschool Cicalengka Kabupaten Bandung Kabupaten Bandung?

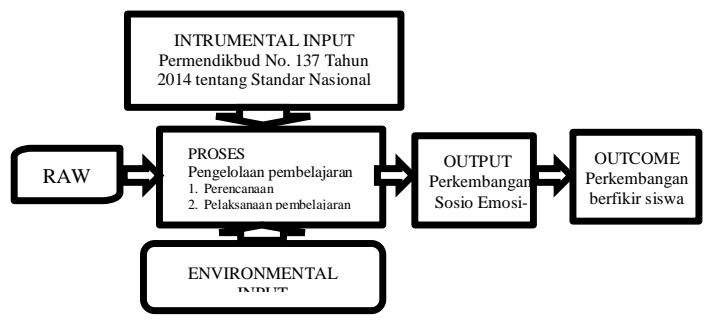

Gambar. 1 Perumusan Masalah

Secara garis besar persoalan yang masih belum optimal pada sosio emosional anak dipengaruhi oleh beberapa faktor row input misalnya (siswa). Faktor instrumental input seperti (Permendikbud No. 137 Tahun 2014 tentang Standar Nasional PAUD, kurikulum, sarana/prasarana, biaya dan sumber daya manusia). Faktor inveronmental input seperti (keluarga, masyarakat, dan stakeholder). Faktor-faktor ini saling berkaitan satu dengan yang lainnya dalam peningkatan mutu lulusan siswa PAUD. Persoalan pengelolaan pembelajaran, turunnya animo siswa, dan kurangnya layanan mainan anak yang disebabkan oleh pengelolaan pembelajaran yang kurang efektif.

Berdasarkan perumusan masalah tersebut di atas, maka hal-hal yang dipandang perlu untuk mengetahui Pengelolaan Pembelajaran Dalam Proses Pengembangan Sosial Emosional Standar PAUD Az-Zahra Islamic Preschool Cicalengka Kabupaten Bandung adalah kemampuan manajerial kepala sekolah, kinerja dan kompetensi guru, serta tenaga kependidikan.

Upaya kepala sekolah dalam meningkatkan mutu layanan dan mutu pembelajaran yaitu melalui Pengelolaan pembelajaran, diarahkan pada aspek kemampuan dalam pengambilan keputusan yang arif dan bijaksana. Kepala sekolah sebagai individu yang bertanggung jawab di sekolah mempunyai kewajiban untuk berusaha agar semua potensi yang ada di sekolanya dapat dimanfaatkan sebaik-baiknya demi tercapainya tujuan yang diharapkan. Oleh karena itu, kepemimpinan kepala sekolah menjadi salah satu faktor penting yang dapat mendorong sumber daya sekolah untuk mewujudkan visi, misi, tujuan, dan sasaran sekolahnya.

\section{Batasan Masalah}

Mengingat luasnya masalah yang telah dirumuskan, maka peneliti membatasi masalah adalah sebagai berikut:

1) Bagaimana Perencanaan Pengelolaan Pembelajaran Dalam Proses Pengembangan Sosial Emosional

2) Bagaimana Pelaksanaan pembelajaran Pengelolaan Pembelajaran Dalam Proses Pengembangan Sosial Emosional

3) Bagaimana Evaluasi Pengelolaan Pembelajaran Dalam Proses Pengembangan Sosial Emosional

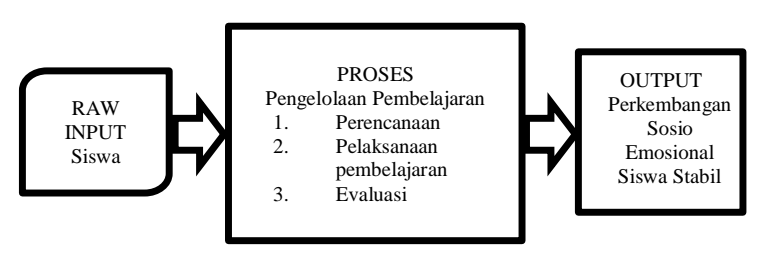

Gambar 2. Batasan Masalah

Sehubungan dengan permasalah yang diteliti, maka penulis hanya membatasi pada Pengelolaan Pembelajaran Dalam Proses Pengembangan Sosial Emosional Standar PAUD Az-Zahra Islamic Preschool Cicalengka Kabupaten Bandung.

Oleh karena itu diperlukan penekanan pada proses peningkatan Pengelolaan Pembelajaran sehingga mencetak anak dengan perkembangan lebih baik.

\section{Pendekatan Penelitian}

Terkait sebuah cara yang digunakan oleh penyusun 
dalam mengungkap, memahami, menggali, mendekati subjek penelitiannya. Sejak awal, peneliti harus mampu menentukan pendekatan yang akan digunakan (pendekatan idealnya bersifat tetap,teknik yang bersifat situasional atau fleksibel (Sugiyono, 2014).

\section{Metode Penelitian}

Jenis Penyusunan Artikel Ini Yang Akan Penulis Gunakan Adalah Jenis Metode Penelitian Deskriptif, Diantaranya Metode Penelitian Kepustakaan Lapangan Dan Observasi, Merupakan Pengumpulan Data Yang Nyata Dan Diperoleh Berdasarkan Sistem Pengelolaan Data Yang Disebut Proses Kepustakaan. Tanpa Dokumen, Data Tidak Akan Menjadi Dokumen Nyata. Penyusunan Dokumen Merupakan Proses Yang Sistematis, Dan Pengelolaan Data Mulai Dari Pengumpulan Hingga Generasi Koleksi Dokumen Dilakukan Secara Sistematis. Tujuan Dari Dokumen Itu Sendiri Adalah Untuk Memperoleh Dokumen Yang Diperlukan Untuk Membuktikan Adanya Kegiatan Yang Terekam Baik Berupa Informasi Maupun Benda.

\section{KAJIAN PUSTAKA}

\section{Landasan Filosofis}

Upayakan untuk meningkatkan pendidikan karakter di jalur pendidikan formal. Namun terdapat perbedaan pendapat antara metode dan metode pendidikan. Mengenai metode ini, beberapa ahli merekomendasikan penggunaan metode pendidikan moral yang berkembang di negara-negara Barat, seperti metode perkembangan moral kognitif, metode analisis nilai, dan metode klarifikasi nilai. Ada pula yang menyarankan untuk menggunakan cara tradisional yaitu dengan menanamkan nilainilai sosial tertentu di kalangan siswa (Ujang Cepi Barlian, 2018: 107).

Ada hubungan yang sangat erat antara filsafat dan pendidikan. Filsafat berusaha membentuk citra manusia dan masyarakat, sedangkan pendidikan berusaha menciptakan citra manusia dan masyarakat. Filsafat pendidikan berusaha menjawab secara kritis berbagai pertanyaan besar tentang pendidikan, seperti apa, mengapa dan bagaimana menyelenggarakan pendidikan.Oleh karena itu, penelitian tentang logika filosofis, etika, estetika, metafisika, epistemologi, dan lain-lain akan berdampak besar bagi perkembangan pendidikan. pengaruh. Karena asas dan hasil kajian tersebut bersumber dari kajian yang mendalam dan sistematis tentang asas kebenaran (Sopyan Sauri, 2007).

\section{Landasan Teoritis}

\section{Pengelolaan Pembelajaran}

Usaha yang dilakukan oleh guru dalam kegiatan pembelajaran atau orang yang membantunya dengan maksud agar tercapai kondisi optimal, sehingga dapat terlaksana kegiatan belajar seperti yang diharapkan. Pembelajaran berarti kepemimpinan atau ketatalaksanaan yang dilakukan oleh guru dalam praktek penyelenggaraan pembelajaran di kelas. Pada Proses mempelajaran bagaimana reaksi gurusiswa berkaitan dengan stimulus dan respons yang terjadi dalam komunikasi guru-siswa. Bentuk reaksi antara lain perhatian, penghargaan (reward), atau teguran (punishment) (Sopyan Sauri, 2003:50).

\section{Langkah Pengelolaan Pembelajaran}

Menurut teori Rusman (2014) terdapat 3 indikator pengelolaan pembelajaran, yaitu: 1) Perencanaan 2) Pelaksanaan pembelajaran a) Kegiatan pendahuluan b) Kegiatan inti c) Kegiatan penutup 3) Evaluasi Bahwa langkah-langkah pengelolaan pembelajaran adalah merencanakan, mengembangkan, melaksanakan, mengevaluasi atau mengevaluasi atau mengevaluasi perbedaan masing-masing anak.

\section{Perencanaan Pembelajaran}

Perencanaan adalah proses manajemen untuk menentukan apa yang harus dilakukan dan bagaimana melakukannya. Dalam merencanakan tujuan yang ingin dicapai, tujuan tersebut diuraikan dan dirumuskan dalam bentuk rencana kerja untuk mencapainya. Isi rencana studi meliputi rencana tahunan, rencana semester, rencana kegiatan mingguan (RKM) bahkan rencana studi satuan (Azwardi, 2015), yang dirumuskan setiap hari atau setiap rapat. Beberapa metode pembelajaran adalah sebagai berikut:

a) Pembiasaan, bahwa metode pembiasaan adalah suatu cara pendidik untuk mengulang hal yang sama secara serius kepada peserta didik agar terbentuk kebiasaan yang baik, sehingga tingkah laku atau keterampilan dapat benar-benar dikuasai, dan Itu akhirnya menjadi kebiasaan, yaitu sulit untuk ditinggalkan.

b) Sosiodrama atau Bermain Peran, bahwa metode bermain peran merupakan metode pengajaran yang dilakukan oleh guru, menekankan bahwa siswa berperan serta dalam meniru masalah sosial untuk membantu siswa belajar mencerminkan nilai-nilai sosialnya sendiri dan membangun empati kepada orang lain. Lainnya, dan mencoba mengembangkan keterampilan sosial dengan melibatkan siswa dalam permainan peran atau drama meniru masalah sosial.

c) Pelaksanaan Pembelajaran, pelaksanaan pembelajaran merupakan implementasi dari RPP. Ada beberapa kegiatan untuk melaksanakan pembelajaran di sekolah, antara lain: kegiatan 
persiapan, kegiatan inti dan kegiatan penyelesaian. Pelaksanaan pembelajaran dapat dikaitkan dengan terjadinya interaksi guru-siswa guna menyampaikan materi pembelajaran kepada siswa untuk mencapai tujuan pembelajaran. Selain itu, ada beberapa langkah dalam melaksanakan pembelajaran anak (Mulyasa, 2012) antara lain: 1) Sebelum masuk kelas 2) Pendahuluan 3) Kegiatan inti 4) Makan dan istirahat 5) Penutup.

d) Evaluasi pembelajaran, kegiatan penilaian pembelajaran yang dilakukan meliputi tiga kegiatan yaitu melalui observasi, catatan anekdot dan portofolio. Dengan bantuan anekdot tersebut, guru dapat menemukan dan mengembangkan metode untuk menyesuaikan dengan kebutuhan dan kesulitan yang dihadapi anak dalam kegiatan pembelajaran (Arifin, 2009). Proses penilaian untuk memahami tingkat keberhasilan yang telah dicapai siswa saat mengikuti pendidikan sebagai berikut:

\section{Penilaian dalam pembelajaran}

Evaluasi rencana pendidikan meliputi keberhasilan anak, keberhasilan guru, dan tingkat kepuasan orang tua anak terhadap hasil yang dicapai. Asesmen anak usia dini dilakukan dengan mengamati, mencatat, dan mencatat aktivitas anak. Evaluasi tidak hanya digunakan untuk mengukur keberhasilan rencana, akan tetapi untuk memanta kemajuan dan perkembangan belajar anak (Damayanti, 2018:17). Adapun teknik penilaian yangdilakukandalam pembelajaran, antara lain:

\section{Pengamatan}

Evaluasi melalui observasi bertujuan untuk mencatat perkembangan sikap siswa melalui observasi, baik sikap siswa terhadap mata pelajaran maupun hal-hal umum. Berikut beberapa pertimbangan saat membuat catatan:

(a) Terdiri dari kata-kata yang menggambarkan situasi atau peristiwa aktual

(b) Rekam kejadian yang tidak disengaja atau tidak terduga

(c) Catatannya koheren, dan insiden itu disebutkan secara konsisten

(d) Rekaman harus dibuat segera setelah kecelakaan.

Tabel 2 format Catatan Anekdot:

\begin{tabular}{l|l}
\hline \multicolumn{2}{c}{ CATATAN } \\
\hline Pengamat: & ANEKDOT \\
Lokasi: & Nama Anak: \\
Hari/Tanggal: & Kelompok usia: \\
\hline
\end{tabular}

Peristiwa:

Komentar/Interpretasi guru:

Sumber: PAUD Az-Zahra Islamic Preschool Cicalengka Kabupaten Bandung. 2020.

\section{Unjuk kerja}

Unjuk kerja sebagai penilaian yang mengharuskan siswa melakukan tugas-tugas dengan gerakan yang diamati, seperti latihan, menari, olahraga menyanyi dan bentuk latihan lainnya.

Tabel 3 Format Unjuk Kerja

\begin{tabular}{c|c|l|c|c}
\hline No & $\begin{array}{c}\text { Hari/ } \\
\text { Tanggal }\end{array}$ & $\begin{array}{l}\text { Kegiatan } \\
\text { Format Unjuk Kerja } \\
\text { Nama : } \\
\text { Indikator : } \\
\text { Kelompok : } \\
\text { Semester/TP : } \\
\text { Pembelajaran }\end{array}$ & $\begin{array}{c}\text { Aspek } \\
\text { yang dinilai }\end{array}$ & $\begin{array}{c}\text { Deskripsi } \\
\text { Unjuk } \\
\text { Kerja }\end{array}$ \\
\hline & & & \\
\hline
\end{tabular}

\section{Pelaporan dan tindak lanjut}

Menurut Rusman (2014) setelah penilaian perkembangan siswa dilaporkan, hasilnya akan dikelola dan ditindaklanjuti. Dalam hasil evaluasi perlu di kelola dalam penarikan kesimpulan dan melaporkan tenaga pendidik guru bagaimana kemajuan anak berdasarkan hasil pembelajaran yang sudah dilaksanakan, guru akan memberikan laporan kegiatan terhadap perkembangan yang sudah terlihat pada anak secara tertulis. Kemudian lacak hasil evaluasi yang diharapkan termasuk:

a) Evaluasi yang dilakukan pendidik sebagai acuan untuk meningkatkan kompetensi diri.

b) Pendidik memanfaatkan hasil evaluasi pada rencana dalam memperbaiki rencana, metode, jenis kegiatan, pelaksanaan dan menyusun alat permainan yang bersifat edukatif, alat sanitasi dan kesehatan, serta meningkatkan kebutuhan kelas maupun lembaga pendidikan anak usia dini, termasuk pada anak yang berkebutuhan khusus.

c) Mengadakan pertemuan dengan orang tua untuk membahas dan menindaklanjuti kemajuan perkembangan anak.

\section{Perkembangan Sosio Emosional}

Aturan yang berlaku pada masyarakat untuk beradaptasi anak pada tingkah lakuanak mengacu pada perkembangan sosial emosional yang berlaku di masyarakat tempat sekitar anak tempat tinggal. Selain itu, Perubahan hubungan pribadi dengan orang lain, perubahan emosi, dan perubahan kepribadian. Sistem sosial menangani komunikasi guru dan siswa, siswa dan siswa, serta komunikasi lain yang mendukung proses pembelajaran. Sistem sosial adalah proses menciptakan lingkungan pendidikan yang kondusif, Sopyan Sauri, 2003: $51)$. 
50 Coopetition, Vol XII, Nomor 1, Maret 2021, 45 - 54

(E-ISSN : 2615-4978, P-ISSN : 2086-4620)

\section{Pengembangan Sosia Emosional}

Perkembangan sosio emosional anak sangat penting karena apabila perkembangan sosial emosional anak baik maka mereka dapat berfokus dan lebih dapat menyerap informasi kepada anak usia dini (Ukti, 2015). Sangat sulit bagi orang yang tidak bekerja keras melindungi emosinya untuk berkomunikasi temannya, dan pada perkembangan suatu proses dapat menjalankan dengan secara efektif dan baik sebagai berikut:

1) Pendekatan secara menyeluruh/holistik

Guru hendaknya mulai rencana perkembangan pembelajaran pada anak berdasarkan konsep keseluruhan. Dengan kata lain, holisme bertujuan sebagai landasan dasar untuk memajukan tumbuh kembang pada anak.

2) Pembelajaran terpadu berbasis tema

Metode pembelajaran ini berdasarkan pada lingkungan dan tentang gagasan pada anak sebagai pokok dasar pikiran pada anak.

3) Pengembangan program kegiatan rutin atau pembiasaan

Perkembangan sosia emosional dapat menjadi dasar untuk dapat di tanamkan sebagai pola tertentu, yaitu perilaku tertib dan disiplin pada penciptaan berdasarkan kondisi terbaik di lingkungannya. Artinya jenis dan metode perilaku dapat mendorong perkembangan sosial dan emosional anak melalui penjadwalan yang berkesinambungan, sehingga perilaku yang diharapkan menjadi kuat dan menjadi bagian dari perilaku positif yang dimilikinya. Penjadwalan berkelanjutan biasanya disebut aktivitas harian.

4. Pedoman kebiasaan pada anak sesuai dengan pedoman, keterbukaan yang lebih baik yang dapat diterima oleh lingkungan sekitar, serta dapat melaksanakan kegiatan terencana.

Terwujudnya perkembangan pada kegiatan sosial emosional melalui kegiatan yang sudah terencana mengacu pada kegiatan yang dilaksanakan secara terencana dan sederhana, yaitu agenda, dan rancangan jangka panjang dan jangka pendek dalam silabus kurikulum guru, yaitu satu hari, satu minggu, Satu bulan, satu tahun dan tahun berikutnya, untuk mendapatkan kegiatan pembelajaran yang terstuktur dan terprogram agar berjalan secara efektif dan efisien dapat dilaksanakan sesuai kurikulum yang terencana untuk tercapai dalam kegiatan.

\section{Deskripsi Analisis Data}

Pada tahap ini mendeskripsikan kegiatan pengelolaan pembelajaran pada usia 4-5 tahun dalam proses perkembangan sosial dan emosional PAUD Az-Zahra Islamic Preschool Cicalengka
Kabupaten Bandung. Mengenai penelitian di peroleh pada pengelolaan, dokumentasi data yang di peroleh oleh menggunakannya metode keputusan yang obyektif dan dapat digunakan sebagai informasi.

Dalam mencari data penelitian tambahan di lengkapi menggunakan metode wawancara dan observasi. Metode observasi, wawancara dan catatan penelitian kualitatif dengan studi kasus deskriptif.

Catat hasil dari proses perkembangan sosial dan emosional pada kelompok usia 4-5 tahun PAUD Az-Zahra Islamic Preschool Cicalengka Kabupaten Bandung berpacu pada teori Mulyasa (2012) yang menyebutkan ada beberapa indikator dalam pengelolaan pembelajaran yaitu:

1) Program Perencanaan

2) Program Pelaksanaan pembelajaran meliputi a) Kegiatan sebelum masuk kelas, b) Kegiatan pendahuluan, c) Kegiatan inti, d) Kegiatan makan dan istirahat dan e) Kegiatan penutup

3) Evaluasi, meliputi Penilaian dan Pelaporan dan tindak lannjut

Berikut ini penulis uraikan hasil literatur tentang manajemen pembelajaran dalam proses perkembangan sosial dan emosional pada kelompok usia 4-5 tahun. Hasilnya dirangkum berdasarkan dua teori (Mulyasa, 2012).

Kegiatan perencanaan pembelajaran dalam proses pengembangan sosial emosional usia 4-5 tahun PAUD Az-Zahra Islamic Preschool Cicalengka Kabupaten Bandung.

Rencana pembelajaran sangat penting bagi guru, melalui rencana guru dapat melaksanakan kegiatan dalam mengajar secara teratur, terus menerus, produktivitas. Pelaksanaan perencanaan pembelajaran guru di PAUD Az-Zahra Islamic Preschool Cicalengka Kabupaten Bandung. menyiapkan dan membuat (a) program tahunan (b) program semester (c). Program mingguan (d). Pertunjukan harian. Rencana pembelajaran yang direncanakan meliputi tujuan pembelajaran.

Tersedianya program tahunan program semester yaitu Setiap tenaga pendidik di PAUD Az-Zahra Islamic Preschool Cicalengka Kabupaten Bandung Diperlukan penyusunan mata kuliah tahunan, mata kuliah semester dan mata kuliah harian, karena jika tidak ada rencana maka dalam pelaksanaan pembelajaran tidak akan berjalan lancar. Minta seorang guru untuk merencanakan kegiatan sehari-hari, termasuk guru tetap dan pendampinga anak oleh guru, sekalipun bersamaan di kelas dan mulai melaksanakan pembelajaran sebelumnya. Sebelum melaksanakan pembelajaran, guru juga harus siap mempersiapkan 
perangkat pembelajaran seperti mata kuliah tahunan, mata kuliah semester dan mata kuliah harian.

Sosio emosional anak sebagai proses pengembangan sebagai penentu tujuan pembelajaran, yaitu hasil yang di peroleh informasi bahwa di PAUD Az-Zahra Islamic Preschool Cicalengka Kabupaten Bandung, dalam rencana tujuan dala pembelajaran ini sebagai penumbuhan emosional social pada siswa yang sudah di rencanakan oleh guru yang harus di selesaikan.

Perkembangan sosio emosional sebagai proses pelaksanaan pembelajaran yang belum terlaksana, misalnya anak yang berani tampil, mematuhi peraturan sekolah dan meningkatkan kesabaran permainan, sabar menunggu giliran, bermain dengan teman, dll. Semua tujuan pembelajaran dimasukkan dalam kurikulum tahunan, silabus semester dan kurikulum harian.

Proses pengembangan sosial emosional di tentukan oleh media dan alat belajar, yaitu selain menetapkan tujuan pembelajaran, tenaga pendidik juga harus bisa menentukan dan memilah sumber belajar dan media belajar yang akan digunakan untuk melaksanakan pembelajaran. Sebelum melaksanakan rencana pembelajaran, guru merencanakan untuk menggunakan media dan perangkat pembelajaran dalam proses perkembangan sosial dan emosional, seperti Krayon, Buku, Puzzle, Pewarna Makanan, Lego, Angron, dll, yang termasuk dalam kurikulum tahunan, silabus semester. Dan pelajaran harian.

Proses pengembangan sosial emosional dalam merencanakan metode relavan, yaitu hasil dokumentasi di peroleh informasi bahwa di PAUD Az-Zahra Islamic Preschool Cicalengka Kabupaten Bandung, Dalam rencana studi, rencanakan terlebih dahulu metode yang sesuai untuk kegiatan. Dalam proses perkembangan sosial dan emosional, nyanyian, kebiasaan dan percakapan digunakan untuk merangsang perkembangan sosial dan emosional.

Kemudian peneliti dapat menganalisis data bahwa guru telah melaksanakan dengan baik dalam perencanaan pembelajaran sebagai berikut: 1) Tersedianya program tahunan, program semester, program harian, silabus. 2) Menentukan tujuan pembelajaran dalam proses perkembangan sosio emosional. 3) Mengidentifikasi media dan perangkat pembelajaran dalam proses perkembangan sosial emosional. 4) Rencanakan metode yang berkaitan dengan proses perkembangan emosional sosial. Oleh karena itu, melalui perencanaan pembelajaran diharapkan proses pembelajaran dapat berjalan dengan efektif.

Proses pengembangan sosial emosional sebagai kegiatan pelaksanaan pembelajaran pada anak usia 4-5 tahun di PAUD Az-Zahra Islamic Preschool Cicalengka Kabupaten Bandung. Setelah tahap pembelajaran berikutnya direncanakan, maka kegiatan pembelajaran dilaksanakan dengan menerapkan kegiatan yang direncanakan tujuan pembelajaran agar tercapai. Menurut Mulyasa (2012), PAUD telah mengambil langkah-langkah sebagai berikut dalam pelaksanaan kegiatan pembelajaran: 1) Kegiatan sebelum kelas. 2) Kegiatan pendahuluan. 3) Kegiatan inti. 4) Acara penutupan. Dalam hal ini peneliti mendokumentasikan kegiatan pelaksanaan pembelajaran di PAUD Az-Zahra Islamic Preschool Cicalengka Kabupaten Bandung, dan peneliti akan menjabarkan sebagai berikut:

a. Proses pengembangan sosio emosional sebagai kegiatan sebelum masuk pembelajaran kelas pada usia 4-5 tahun

Dalam kegiatan sebelum kelas, anak dipersilakan untuk berjabat tangan dan membiasakan meletakkan tas di rak tas, kemudian mengajari mereka untuk menuliskan nama mereka ketika mereka absen, kemudian mengaji dan bermain di kampus, dan membiarkan anak bermain dengan teman-temannya agar anak tidak bosan.

Untuk memperkuat hasil dokumentasi, peneliti melakukan observasi langsung kegiatan berdasarkan observasi peneliti di PAUD Az-Zahra Islamic Preschool Cicalengka Kabupaten Bandung kegiatan sebelum masuk kelas sudah di lakukan dengan baik sesuai dengan indikator: guru membiasakan anak berjabat tangan. Guru membiarkan anak bermain bersama temantemannya. Guru membiasakan anak meletakan sepatu pada tempatnya. Guru membiasakan anak menunggu giliran sebelum masuk kelas.

b. Proses pengembangan sosial emosional pada kegiatan pendahuluan pada usia 4-5 tahun

Sebelum melaksanakan kegiatan inti, guru melaksanakan beberapa kegiatan yang bermanfaat sebagai kegiatan persiapan untuk mempersiapkan anak menghadapi kegiatan tersebut.

Berdasarkan hasil yang di peroleh informasi bahwa di PAUD Az-Zahra Islamic Preschool Cicalengka Kabupaten Bandung pada kegiatan pendahuluan biasanya Mintalah anak-anak untuk berdoa terlebih dahulu, dan disediakan rangkaian kegiatan, kemudian untuk kegiatan ibadah, ini adalah kegiatan rutin.

c. Kegiatan inti dalam proses pengembangan sosial emosional usia 4-5 tahun.

Kegiatan pembelajaran inti penting dalam mencapai tujuan pembelajaran yang sudah ditetapkan. Berdasarkan hasil dokumen, informasi dapat diperoleh dari kegiatan inti dengan 
menggunakan metode yang telah direncanakan sebelumnya dan materi pembelajaran Rencana Pelaksanaan Pembelajaran Harian untuk menyasar emosi sosial, biasanya menggunakan metode untuk mematuhi pembiasaan sebagai aturan kegiatan yang akan dilakukan, dan membiarkan anak membiasakan diri untuk mandiri dalam menyelesaikannya. Perilaku sebelum tugas. Aktivitas ini juga menggambarkan aktivitas yang akan dilakukan.

d. Proses pengembangan sosial emosional dalam kegiatan makan dan istirahat pada usia 4-5 tahun.

Menurut Mulyasa (2012), kegiatan ini pencapaian yang berkaitan dengan kegiatan makan anak, sebagai contoh di kelas atau saat istirahat, disiplin, disiplin makan, perasaan sosial, dan kerja sama.

Berdasarkan hasil dokumen, kegiatan anak usia dini pada pada saat jam istirahat mengajarkan anak untuk belajar sholat, sesudah sholat makan bersama temannya dengan antri lalu berdoa dan tindak lupa menjaga kebersihan lalu anak melanjutkan bermain kembali bersama temannya.

e. Proses pengembangan sosial emosional pada kegiatan penutup pada anak usia 4-5 tahun.

Kegiatan inti yang diberikan oleh guru untuk mengakhiri yang bertujuan untuk mengevaluasi dan mengevaluasi proses belajar anak. Menurut Rusman, (2014), kegiatan penutup merupakan kegiatan dari akhir pembelajaran yang dilakukan dalam bentuk ringkasan atau kesimpulan, evaluasi, umpan balik, dan tindak lanjut. Berdasarkan hasil "setelah kegiatan selesai, kegiatan diakhiri dengan menanyakan kembali kepada anak-anak tentang kegiatan yang telah mereka lakukan, kemudian berdoa.

\section{Evaluasi pembelajaran dalam proses pengembangan sosial emosional anak usia 4-5 tahun.}

Setelah guru merencanakan dan melaksanakannya, guru harus melakukan penilaian, yaitu menilai perkembangan sosial dan emosional anak, serta melaporkan dan menindaklanjutinya. Tujuan dari laporan ini adalah untuk memungkinkan orang tua memahami pertumbuhan anak-anak mereka selama mereka belajar di organisasi hiburan. Laporan yang diberikan kepada orang tua berupa laporan perkembangan anak. Setelah penilaian perkembangan siswa dilaporkan, hasilnya akan dikelola dan ditindaklanjuti.

\section{Penilaian hasil pembelajaran dalam proses pengembangan sosial emosional anak usia 4-5 tahun.}

Berdasarkan hasil dokumen diperoleh informasi bahwa evaluasi kinerja akademik sedang berlangsung, “ Evaluasi dilakukan pada saat kegiatan sekolah, setiap hari, minggu, dan bulan untuk mengevaluasi anak melalui observasi, pekerjaan anak, dan Jika sikap anak luar biasa, maka hal itu tidak biasa baginya. Itu memang akan dicatat dalam anekdot, dan kemudian ada portofolio.

Proses pengembangan sosial emosional pada pelaporan dan tinjak lanjut anak usia 4-5 tahun.

Hasil dokumen informasi yang didapat adalah laporan kegiatan dan tindak lanjut hasil belajar. "Untuk kegiatan melaporkan kepada orang tua, biasanya berkomunikasi melalui handphone terlebih dahulu, atau melaporkan pada masa tumbuh kembang anak saat orang tua menjemput anak, pada akhir semester. Menulis seperti rapor anak untuk tindak lanjut.

\section{Tabel 4 Hasil Presentase Penelitian}

\begin{tabular}{cccc}
\hline No & Kriteria & $\begin{array}{c}\text { Jumlah } \\
\text { Siswa }\end{array}$ & Hasil \\
\hline 1 & Belum Berkembang & 0 & $0 \%$ \\
2 & Mulai Berkembang & 10 & $70,59 \%$ \\
3 & Berkembang sesuai Harapan & 7 & $29,41 \%$ \\
4 & Berkembang sangat Baik & 0 & $0 \%$ \\
\hline \multicolumn{4}{c}{ Jumlah } \\
\hline
\end{tabular}

Sumber: Hasil Presentase, 2020.

Berdasarkan hasil penelitian para peneliti tentang perkembangan sosial dan emosional, indikatorindikator tersebut memiliki beberapa indikator sebagai berikut: kemandirian anak dalam melaksanakan kegiatan, saling membantu sesama teman, membantu teman, anak dapat mematuhi peraturan, dan anak saling menghargai sesama temannya. Terlihat bahwa $0 \%$ "anak belum berkembang", 70,59\% "anak sudah mulai berkembang", 29,41\% "anak berkembang sesuai harapan" dan $0 \%$ "anak berkembang sangat baik".

\section{HASIL DAN PEMBAHASAN}

Mengenai analisis data deskriptif, di PAUD AzZahra Islamic Preschool Cicalengka Kabupaten Bandung Dalam rencana studi terdapat beberapa perangkat pembelajaran seperti rencana tahunan, rencana semester dan rencana harian untuk mencapai tujuan yang efektif dan efisien. Dengan mendeskripsikan ciri-ciri teknik pembelajaran yang direncanakan sebelumnya.'Untuk mencapai tujuan pembelajaran dirumuskan dalam bentuk rencana semester,"silabus kurikulum, rencana mingguan, dan rencana harian.Oleh karena itu, guru harus membuat rencana untuk mencapai tujuan yang diharapkan dalam" proses perkembangan sosial emosional.

Guru hendaknya merencanakan media dan perangkat pembelajaran sebelum pembelajaran dalam proses perkembangan sosial dan emosional, 
seperti krayon, buku, puzzle, pewarna makanan, Lego, Angron, dll. Ini termasuk dalam mata kuliah tahunan, silabus semester dan mata kuliah harian.

Perencanaan melibatkan pemilihan tujuan yang ingin dicapai dan menghitung serangkaian tindakan yang mungkin dicapai. Tahapan ini perlu diperhatikan secara detail, misalnya_tujuan proses pembelajaran' yang dikemukakan oleh instruktur, tujuan yang dinegosiasikan dan dicapai oleh individu maupun kelompok.

Kegiatan pra kelas terlaksana dengan baik guru meminta anak-anak untuk berjabat tangan. Guru mempersilahkan anak bermain dengan temannya, guru meminta anak untuk memakai sepatu dan menunggu mereka masuk kelas.

Kegiatan inti dilaksanakan dengan baik yaitu: guru membiasakan anak dengan tugasnya masingmasing. Guru membiasakan anak-anak dengan pembelajaran dan permainan kelompok. Guru membiasakan anak untuk mengambil dan mengembalikan' alat tulisnya.

Dalam kegiatan makan dan istirahat, guru akan melaksanakan rangkaian kegiatan dengan baik, sebagai berikut guru meminta anak berbaris saat cuci tangan, guru menyuruh anak mau berbagi makanan dengan temannya, saat istirahat guru memberi kesempatan kepada anak untuk memilih favorit permainan.

Pada kegiatan penutup guru mengajak anak untuk berdoa, namun kedua indikator tersebut masih belum terpenuhi yaitu guru mengajukan tanya jawab kepada anak untuk memahami apakah mereka berhasil menumbuhkan emosi sosial anak dalam kegiatan. Tanyakan kepada anak-anak bagaimana perasaan mereka selama kegiatan. Mengakhiri mata kuliah bukanlah mengucapkan salam penutup, hamdallah atau doa di akhir setiap kegiatan pembelajaran, karena kegiatan tersebut sebaiknya dilakukan di akhir setiap kegiatan. Beberapa upaya yang dapat dilakukan guru untuk mengakhiri kursus antara lain meringkas atau meringkas poin-poin utama kursus, memberikan dorongan psikologis atau sosial kepada siswa, memberikan panduan untuk topik kursus berikutnya, dan mengevaluasi topik yang baru saja selesai.

Dalami kegiatan evaluasi guru sudah terlaksana dengani baik, yaitu guru selalu mengamati setiap perkembangan emosi dan sosiali yang terjadi pada anak, dan guru selalu mencatat hasil evaluasi dalam bentuk evaluasi harian, mingguan, dan bulanan. Dalam pelaporan dan kegiatan tindak lanjut, guru melaporkan perkembangan sosial anak melalui lisan dan tulisan, dan guru menindaklanjuti hasil penelitian.

Dilihat dari beberapa indikator yang dikemukakan oleh teori Rusman dan Mulyasa, pengelolaan pembelajaran dalam proses pengembangani emosional sosial dilakukan melalui kegiatan perencanaan, pelaksanaan dan evaluasi. Ternyata di bidang ini apa yang dilihat peneliti disebabkan oleh guru di PAUD Az-Zahra Islamic Preschool Cicalengka Kabupaten Bandung Pekerjaan ini terlaksana dengan baik, namun masih terdapat beberapa indikator yang belum terlaksana, yaitu guru tidak lagi meminta kepada anak untuk melihat apakah kegiatan yang dilakukan dalam menumbuhkan emosi sosial anak berhasil. Guru tidak menanyakan kepada anak bagaimana perasaan mereka dalam memahami emosi sosial dalam kegiatan tersebut.

Di lihat dari hasil di lapangan yang di lakukan peneliti terhadap perkembangan sosial emosional dari 17 anak bahwasanya $0 \%$ anak belum berkembang, $70,59 \%$ anak sudah mulai berkembang, 29,41\% anak berkembang sesuai harapan dan $0 \%$ anak berkembang sangat baik.

\section{SIMPULAN DAN SARAN}

\section{Simpulan}

Berdasarkan pembahasan dan hasil penelitian tentang pengelolaan pembelajaran dalam proses pengembangan sosial emosional PAUD Az-Zahra Islamic Preschool Cicalengka Kabupaten Bandung kegiatan guru dimulai dengan proses perencanaan pembelajaran guru dan melaksanakan tugasnya dengan baik sesuai dengan berbagai indikator yaitu tersedianya program tahunan, program semester, program harian.

Proses pelaksanaan pembelajaran guru sangat baik, diantaranya guru membuat anak-anak bersalaman. Guru mengijinkan anak bermain dengan temannya, guru membiasakan anak memakai sepatu, guru menyuruh anak bergiliran di kelas, guru mengenalkan aturan kegiatan yang akan dilakukan, guru membuat anak menghormati temannya yang memimpin sholat sebelum belajar, guru membuat anak terbiasa untuk mengerjakan pekerjaan rumah sendiri, biarkan guru membiasakan diri dengan pembelajaran anak dan permainan kelompok, Guru membuat anak terbiasa mengambili dan mengembalikan alati tulis sendiri, guru meminta anak berbaris saat mencuci tangan, guru mengajak anak mau berbagi makanan dengan temannya, dan guru memberi kesempatan pada anak untuk memilih permainan favoritnya saat istirahat. Dilihat dari beberapa indikator pembelajaran dan pelaksanaan, terdapat dua indikator yang tidak dilaksanakan dalami kegiatani penutup yaitu pada kegiatan penutup guru tidak menanyakan tanya jawab kepada anak untuk melihat kegiatan yang dilakukan dalam pembinaan aspek sosial dan emosional anak. apakah berhasil. Guru tidak menanyakan kepada anak bagaimana perasaan 
54 Coopetition, Vol XII, Nomor 1, Maret 2021, 45 - 54

(E-ISSN : 2615-4978, P-ISSN : 2086-4620)

mereka dalam memahami emosi sosial dalam kegiatan tersebut.

Kegiatan evaluasi manajemen pembelajaran dalam proses perkembangan sosiali emosional terlaksana dengan baik, yaitu: guru menggunakan observasi, hasil karya anak, portofolio, dan anekdoti untuk evaluasi rutin. Guru juga akan meringkas penilaian anak dari evaluasi harian, mingguan dan bulanan, kemudian secara lisan guru akan melaporkan perkembangan sosial dan emosional anak, yaitu berinteraksi langsung dengan orang tua dan wali siswa, serta menggunakan bentuk tertulis yaitu rapor guru juga tindak lanjuti untuk memperbaiki kekurangan dalam kegiatan yangi dilakukan.

Maka dapati di simpulkan bahwa Pengelolaan pembelajaran dalam proses pengembangan sosial emosional PAUD Az-Zahra Islamic Preschool Cicalengka Kabupaten Bandung meskipun masih ada dua indikator yang belum dilaksanakan, namun guru masih berprestasi sesuai dengan indikatornya Dilihat dari tingkat perkembangan sosial dan emosional anak, keberhasilan guru sudah baik.

\section{Saran}

Berdasarkan hasili penelitian dan pembahasan, maka peneliti mengemukakan saran kepada pihak-pihak terkait diantaranya sebagai berikut:

Kepada guru PAUD Az-Zahra Islamic Preschool Cicalengka Kabupaten Bandung, dalam proses perkembangan sosial dan emosional, media dan metode pembelajaran yang sesuai dan lebih beragam dapat digunakan untuk melaksanakan pembelajaran. Selain itu dapat melakukan kegiatan pembukaan dan penutupan dengan lebih baik untuk mencapai tujuan pembelajaran yang diharapkan.

Untuk pihak sekolah PAUD Az-Zahra Islamic Preschool Cicalengka Kabupaten Bandung dalam proses perkembangan sosial emosional, guru dapat diberikan supervisi lebih untuk melaksanakan kegiatan penyelesaian dalam pengelolaan pembelajaran PAUD Az-Zahra Islamic Preschool Cicalengka Kabupaten Bandung.

Dalam proses perkembangan sosial dan emosional, lebih meningkatkan kelengkapan perangkat dan sumber belajar, serta lebih memperhatikan kegiatan guru untuk mencapai tujuan pembelajaran yang tepat sasaran dan efisien.

Untuk peneliti selanjutnya, penulis berharap dapat melakukan penelitian yang lebih mendalam tidak hanya pada tahapan perkembangan sosial dan emosional, serta tahapan perkembangan lainnya anak kelompok usia PAUD ditemukan pada tahap perencanaan, pelaksanaan dan evaluasi pengelolaan pembelajaran.

\section{DAFTAR PUSTAKA}

Arifin, Z. (2009). Evaluasi Pembelajaran. Bandung: PT Remaja Rosdakarya.

Azwardi. (2015). Manajemen Pembelajaran Paud. Manajer Pendidikan, vol. 9, No.1.

Barlian, U. C. (2018). Pendidikan Nilai Dalam Budi Pekerti. Journal Cakrawala IAINU Kebumen Program Studi Manajemen Pendidikan Islam (MPI). Vol I. No. 1.

Damayanti, E. (2018). Manajemen penilaian pendidikan anak usia Dini Pada Tamankanak-Kanak Citra Samata Kabupatengowa. Journal Ofearly Childhood Education, Vol.1, No.1.

Fory, N. (2016). Strategi Pengelolaan Pembelajaran. Gorontalo: Ideas Publishing.

Maulana, A. (2020). Pengaruh Kompetensi dan Kompensasi Terhadap Kinerja Pegawai Primer Koperasi Kartika Artileri Berdaya Guna Sepanjang Masa Pusat Kesenjataan Artileri Medan Kota Cimahi, X(2), 83-96.

Mulyasa, E. (2012). Manajemen Paud. Bandung: PT Remaja Rosdakarya.

Rusman. (2014). Model-Model Pembelajaran. Jakarta: Pt Raja Grapindo Persada.

Sary Yulia, Yusrizal, K. (2015). Manajemen Pembelajaran Sentra Dan Lingkaran Pada Paud Subulussalam Kota Banda Aceh. Jurnal Administrasi Pendidikan Pascasarjana Universitas Syiah Kuala, Volume 3, No. 4,.

Sauri, S. (2003). Pengembangan Strategi Pendidikan Berbahasa Santun di Sekolah. Jurnal Universitas Pendidikan Indonesia.

Sauri, S. (2007). Sekilas tentang pendidikan nilai. Kopus Politeknik UNSI Kabupaten Sukabumi.

Sugiyono. (2014). Metode Penelitian Manajemen. Alfabeta. Bandung.

Suharsimi, A. (1996). Pengelolaan Pembelajaran Pada Siswa. Jakarta: Raja Grafindo Persada.

Ukti, L. (2015). Pengaruh Metode Dan Pendekatan Pembelajaran Terhadap Penguasaan Konsep Matematika. Jurnal Formatif, Vol. 5, NO. 3. 